\title{
Pengaruh Diet Sambal Tomat Ranti pada Struktur dan Fungsi Hepar Tikus yang Diinduksi Tawas
}

\section{The Effect of "Sambal Tomat Ranti" on Structure and Function of Alum-Induced Rat Liver}

\author{
Erna Sulistyowati $i^{1}$, Yudi Purnomo ${ }^{1}$, Sofia Nuri', Fajar Audra $P^{2}$ \\ ${ }^{1}$ Laboratorium Patologi Anatomi Fakultas Kedokteran Universitas Islam Malang \\ ${ }^{2}$ Program Studi Pendidikan Dokter Fakultas Kedokteran Universitas Islam Malang
}

\begin{abstract}
ABSTRAK
Masyarakat Indonesia mempunyai kebiasaan mengkonsumsi sambal yang mengandung antioksidan. Paparan radikal bebas salah satunya tawas yang terdapat pada air maupun makanan bisa merusak struktur dan fungsi hepar. Penelitian ini bertujuan untuk membuktikan pengaruh diet sambal yakni paduan cabe rawit (Capsicum frutescens) dengan tomat ranti (Lycopersicum pimpinellifolium Mill) pada struktur hepar dan kadar SGOT dan SGPT tikus yang dinduksi tawas secara akut. Penelitian eksperimental laboratorium dilakukan dengan post test only with control group design. Hewan coba tikus dibagi menjadi enam kelompok yaitu kontrol negatif, kontrol positif (induksi tawas 8\%), kelompok perlakuan diet tomat ranti $100 \%$, paduan tomat ranti 100, dengan cabai rawit 25\%, 50\% dan 100\%. Struktur hepar diamati dengan menghitung jumlah nekrosis sel melalui pulasan Hematoxylin Eosin. Fungsi hepar diamati melalui pemeriksaan kadar SGOT dan SGPT. Analisa data menggunakan uji One Way ANOVA, dilanjutkan dengan post hoc test menggunakan Least Significant Difference (LSD).Pemberian cabai rawit dapat meningkatkan jumlah nekrosis sel hepar dan meningkatkan kadar SGOT dan SGPT secara signifikan bila dibandingkan dengan pemberian tomat ranti (tanpa cabai rawit). Penambahan cabai rawit meningkatkan kerusakan struktur dan fungsi hepar yang diinduksi tawas.
\end{abstract}

Kata Kunci: Cabai, fungsi hepar, sambal, struktur, tomat ranti, tawas

\begin{abstract}
Indonesian has a habit of eating sambal, a kind of chili sauce that contains antioxidants. Exposed to free radicals, like alum which found on water or food will lead to structure and function damage of the liver. The aims of this research are to determine the effect of sambal tomat ranti (Lycopersicum pimpinellifolium Mill and Capsicum frutescens) on liver tissue and the levels of SGOT and SGPT on alum-induced rat. Laboratory experimental studies was performed with a control group post-test only design. Wistar strain Rattus novergicus, male, were divided into six groups:negative control, positive control (8\% alum-induced), ranti tomato $100 \%$ diet, combination of ranti tomato $100 \%$ with cayenne pepper $25 \%$, 50\% and $100 \%$. The liver tissue was observed by counting the number of cell necrosis. The liver function were observed based on the degree of transaminase (AST and ALT). Their elevation can provide some clues of liver damage. The test data analysis using One Way ANOVA, followed by post hoc test using the Least Significant Difference (LSD). Administratif of cayenne pepper can increase the number of hepatic cell necrosis and increased levels of AST and ALT significantly when compared to administration of ranti tomato only. Supplementation cayenne pepper induce structure and functional damage of aluminduced liver.
\end{abstract}

Keywords: Alum, cayenne pepper, chilli sauce, liver, tomato ranti

Jurnal Kedokteran Brawijaya, Vol. 27, No. 3, Februari 2013; Korespondensi: Erna Sulistyowati. Laboratorium Patologi Anatomi Fakultas Kedokteran Universitas Islam Malang, Jl. Mayjen Haryono 193 MalangTel. (0341) 578920Email: ernakertosono@yahoo.co.id 


\section{PENDAHULUAN}

Sambal merupakan indigenous food yang sudah menjadi bagian hidup masyarakat Indonesia dalam menikmati makanan karena iklimnya yang tropis (1). Sambal identik dengan cabai rawit yang banyak mengandung vitamin $A$ dibandingkan cabai lainnya, selain itu juga sebagai sumber vitamin $C$ yang sangat baik $(2,3)$. Cabai rawit juga mengandung kapsaisin yang memberikan rasa pedas dan berkhasiat untuk melancarkan aliran darah. Kapsaisin, yang merupakan senyawa golongan terpenoid, juga berkhasiat sebagai antibiotik. Rasa pedas pada lidah menimbulkan rangsangan ke otak untuk mengeluarkan endorfin yang dapat menghilangkan rasa sakit dan menimbulkan perasaan lebih sehat. Penelitian menunjukkan bahwa cabai rawit dapat mengurangi kecenderungan terjadinya penggumpalan darah (trombosis), menurunkan kadar kolesterol dengan cara mengurangi produksi kolesterol dan trigliserida di hepar (4). Kapsaisin dalam kadar tertentu dapat bersifat toksik dan menimbulkan ancaman kesehatan (4). Ciri khas paduan olahan sambal adalah cabe dan tomat. Ada aneka jenis tomat yang bisa dibuat sambal diantaranya tomat ranti. Tomat ranti, yang dalam bahasa latin disebut Lycopersicum pimpinellifolium Mill, merupakan jenis tomat liar yang memiliki kadar likopen 40 kali lebih banyak dibanding tomat yang biasa kita konsumsi (atau yang dalam bahasa latin disebut Lycopersicum esculentum Mill). Selain itu tomat ranti juga mengandung vitamin $C$ tiga kali lebih banyak dibanding jenis tomat yang lain $(5,6)$. Dengan demikian sambal tomat ranti mempunyai kandungan antioksidan yang cukup banyak dan diduga berpengaruh baik pada struktur dan fungsi hepar akibat paparan radikal bebas seperti tawas.

Saat ini banyak zat kimia berbahaya yang digunakan sebagai bahan tambahan makanan, salah satunya tawas. Pemberian tawas pada air yang digunakan untuk merendam ikan sebelum diasapkan, dengan tujuan agar ikan menjadi lebih putih, kenyal, konsistensinya kesat, mengurangi rasa pahit dan bau amis (7). Tawas juga digunakan untuk mengolah air oleh perusahaan pengelola air minum, yakni sebagai koagulan penjernih air. Kementerian Kesehatan sudah menetapkan batas kadar penggunaan tawas sebagai bahan tambahan makanan maupun minuman karena kandungan logam berat pada tawas (8). Berdasarkan penelitian oleh Haribi dan Yusrin membuktikan bahwa suplementasi tawas dalam pakan dengan konsentrasi $2 \%, 4 \%, 6 \%, 8 \%$ selama paparan $2,4,6$ dan 8 minggu pada tikus Rattus norvegicus mengakibatkan kerusakan jaringan pada organ hepar dan ginjal (9). Tawas mempunyai nama lain aluminium sulfat dengan rumus kimia $\mathrm{Al}_{2}\left(\mathrm{SO}_{4}\right)_{3}$. Tawas berupa kristal putih berbentuk gelatin dengan sifat dapat menarik partikelpartikel lain sehingga mudah mengendap bila larut di dalam air. Tawas dapat masuk ke dalam tubuh manusia melalui makanan atau minuman atau lewat inhalasi sehingga menyebabkan paparan radikal bebas di dalam jaringan tubuh (9). Radikal bebas ini selanjutnya akan dimetabolisme oleh hepar dalam proses detoksifikasi dan bisa menyebabkan kerusakan jaringan sel hepar dan bahkan merusak organela sel seperti mitokondria, nukleus dan organela lain. Kerusakan tersebut dapat berupa degenerasi, akumulasi intraseluler, nekrosis, apoptosis, inflamasi, dan regenerasi. Pada fase akut, nekrosis sel hepar lebih sering ditemukan daripada jenis kerusakan lainnya (10). Penelitian ini dilakukan dengan tujuan untuk mengetahui pengaruh paduan cabe rawit dan tomat ranti pada struktur histopatologi hepar dan kadar SGOT dan SGPT tikus Rattus novergicus yang dinduksi tawas secara akut.

\section{METODE}

\section{Rancangan Penelitian}

Penelitian dilaksanakan secara eksperimental laboratorik dengan control group post test only design. Penelitian dilakukan untuk mengetahui pengaruh perasan buah tomat ranti (Lycopersicum pimpinellifolium Mill.) dengan atau tanpa cabai rawit (Capsicum frutescens) pada tikus yang diinduksi tawas selama satu minggu. Rancangan yang digunakan seperti penentuan dosis tomat ranti, pengelompokan hewan coba, merupakan adaptasi dari hasil penelitian sebelumnya oleh Makhdyaksa (11). Penelitian ini dilaksanakan di Laboratorium Biokimia Fakultas Kedokteran Universitas Islam Malang dan Laboratorium Kimia Universitas Muhammadiyah Malang selama periode tiga bulan.

\section{ProsedurPenelitian}

Hewan coba yang digunakan adalah tikus wistar (Rattus novergicus) berjenis kelamin jantan, berusia sekitar 2-3 bulan, dan kisaran berat badan 130-180 gram biakan lokal dengan kondisi sehat yang ditandai dengan gerak aktif, berbulu halus, dan matanya berwarna merah jernih. Penelitian ini menggunakan hewan coba tikus (Rattus novergicus) strain wistar jantan, berumur sekitar 2-3 bulan, berat badan 130-180 gram. Alasan menggunakan tikus putih strain wistar sebagai sampel populasi dalam penelitian ini adalah karena ini mudah didapatkan, tahan terhadap kondisi laboratorium dan berbagai perlakuan, mempunyai sensitifitas tinggi terhadap obat (12). Penggunaan tikus dipilih yang berumur sekitar 3 bulan, dengan berat badan kurang lebih 150 gram merupakan kriteria tikus sehat (13).

Pembagian kelompok perlakuan ini dilakukan dengan cara randomisasi. Tikus dibagi menjadi 6 kelompok perlakuan dengan 5 tikus per kelompok. Pada tahap pertama dilakukan eksplorasi induksi tawas dengan konsentrasi $2 \%$, $4 \%$, 6\%, dan $8 \%$ selama 1 minggu. Pada tahap kedua, sampel dibagi menjadi kelompok 1 (pemberian aquades sebagai kontrol), kelompok 2 (induksi tawas 8\%), kelompok 3 (induksi tawas $8 \%+$ perasan buah tomat ranti 100\%), kelompok 4 (induksi tawas $8 \%+$ perasan buah tomat ranti $100 \%+$ perasan buah cabai rawit $25 \%$ ), kelompok 5 (induksi tawas 8\%+ perasan buah tomat ranti $100 \%+$ perasan buah cabai rawit 50\%), dan kelompok 6 (induksi tawas $8 \%+$ perasan buah tomat ranti $100 \%+$ perasan buah cabai rawit 100\%).

\section{Pembuatan Perasan Buah Tomat Ranti dan Cabai Rawit}

Buah tomat ranti dan cabai rawit dicuci sampai bersih kemudian dihaluskan dengan blender tanpa diberi air. Buah tomat ranti dan cabai rawit yang telah hancur kemudian disaring dengan menggunakan kertas saring. Larutan hasil penyaringan ini merupakan konsentrasi perasan buah tomat ranti dan cabai rawit $100 \%$. Larutan ini kemudian diencerkan dengan menggunakan aquadest hingga didapatkan konsentrasi 25\% (75 ml aquadest ditambah $25 \mathrm{ml}$ perasan buah cabai rawit) dan $50 \%$ (50 ml 
aquadest ditambah $50 \mathrm{ml}$ perasan buah cabai rawit).

\section{Perlakuan}

Pada penelitian tahap pertama dilakukan optimasi dosis tawas. Tikus diberi induksi tawas 30 menit setelah pemberian pakan tikus, melalui oral (per sonde lambung). Pada tahap kedua dilakukan untuk mengetahui pengaruh perasan buah tomat ranti dengan atau tanpa cabai rawit pada tikus dengan paparan tawas. Buah tomat ranti dan cabai rawit diberikan 30 menit sebelum pemberian pakan. Induksi tawas diberikan 30 menit setelah pemberian pakan. Pemberian tawas dan perasan buah diberikan secara oral (per sonde lambung), diharapkan dosis yang masuk dalam tubuh tikus sesuai dengan dosis penelitian, sehingga tidak menimbulkan bias. Pemberian tawas dilakukan setelah pemberian pakan tikus, sehingga diharapkan stres yang dialami tikus tidak terlalu tinggi. Selain itu dengan pemberian setelah pakan, tingkat iritasi organ pencernaan lain akan cenderung berkurang sehingga diharapkan tidak lagi menyebabkan bias hasil penelitian.

\section{Pengecatan Hematoxylin Eosin}

Hepar yang telah direndam formalin $10 \%$ dipotong hingga berukuran (10-15) $\mathrm{mm} \times$ (10-15) $\mathrm{mm} \times 5 \mathrm{~mm}$. Selanjutnya dilakukan proses dehidrasi, clearing, impregnasi, dan embedding. Setelah itu, dilakukan proses pemotongan dengan menggunakan mikrotom hingga didapatkan irisan setebal 3-5 $\mu \mathrm{m}$. Selanjutnya dilakukan proses pewarnaan Hematoxylin Eosin (HE). Irisan preparat yang menempel pada gelas objek selanjutnya direndam berturut-turut ke dalam xylol (2 menit), xylol (2 menit), etanol absolut (1 menit), etanol absolute (1 menit), etanol 95\% (1 menit), etanol 95\% (1 menit). Setelah itu disiram dengan air mengalir (10-15 menit), dicelup empat kali ke air. Kemudian direndam dalam larutan hypo selama tiga menit dan dibilas dengan air mengalir selama 10 menit. Langkah selanjutnya direndam dalam larutan mayer's haematoxylin selama 5 menit, dibilas dengan air mengalir selama 20 menit. Selanjutnya preparat direndam bertahap ke dalam larutan eosin ( 5 detik -2 menit), etanol 95\% (2 menit), etanol 95\% (2 menit), etanol absolut (2 menit), etanol absolut ( 2 menit), etanol absolut ( 2 menit), $x y l o l$ (2 menit), xylol (2 menit), xylol (2 menit). Langkah selanjutnya dilakukan mounting untuk menutup preparat dengan cover slip dan direkatkan dengan perekat merk Entelan.

\section{Teknik Penghitungan Nekrosis Sel Hepar}

Pengamatan dan penghitungan struktur hepar dilakukan dengan menghitung jumlah nekrosis sel hepar. Penghitungan dilakukan di bawah pengamatan mikroskop binokuler merk yang ditinjau dari 15 lapang pandang. Pengamatan dilakukan dengan memperhatikan struktur histologi zona hepar yakni zona I, II, dan III. Pada satu gelas obyek terdapat tiga preparat. Penghitungan sel nekrosis dilakukan dengan menghitung rata-rata jumlah sel nekrosis per zona hepar. Pengamatan zona I, II, dan III hepar dilakukan dengan mikroskop perbesaran 100 kali. Sedangkan penghitungan jumlah sel nekrosis dilakukan dengan mikroskop perbesaran 400 kali. Identifikasi sel hepar yang bila dijumpai adanya kariolisis serta membran sel yang pecah. Penghitungan jumlah sel nekrosis dilakukan oleh dua orang untuk mengurangi kesalahan penelitian
Pemeriksaan Kadar SGOT (Serum glutamic oxaloacetic transaminase) dan SGPT (Serum glutamic pyruvic transaminase)

Pemeriksaan kadar SGOT dan SGPT menggunakan metode spektrofotometri. Tahapan pemeriksaan yakni diawali dengan membersihkan alat dan menyiapkan bahan. Reagen A (L-alanin dan NADH) $1000 \mu \mathrm{L}$ dimasukkan ke dalam kuvet. Sampel $100 \mu \mathrm{L}$ serum ditambahkan dalam kuvet. Sampel diinkubasi pada suhu $37^{\circ} \mathrm{C}$ selama satu menit. Reagen B (2-Oxoglutarat dan LDH) $250 \mu \mathrm{L}$ ditambahkan, dicampur dan diinkubasi satu menit pada suhu ruang. Hasil dibaca dengan spektrofotometer Cobas Mira.

\section{Teknik Analisa Data}

Data dianalisa sebagai data kelompok dengan menghitung rata-rata (mean) tiap kelompok dan diuji dengan uji statistik yang sesuai. Data ditampilkan sebagai mean \pm

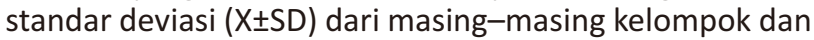
disajikan dalam bentuk tabel. Hasil penghitungan nekrosis sel hepar setiap kelompok hewan coba dibandingkan dengan uji statistik. Uji Independent Sample T-test dilakukan untuk membandingkan perbedaan mean pada setiap kelompok guna mengetahui peran tawas dan perubahan jumlah nekrosis sel pada variabel tergantung. Peran suplementasi tomat ranti dengan atau tanpa cabai rawit diuji dengan uji perbedaan mean setiap kelompok dengan kelompok kontrol menggunakan One Way ANOVA.

\section{HASIL}

Tabel 1 menunjukkan bahwa induksi tawas menyebabkan peningkatan jumlah nekrosis sel hepar. Semakin tinggi kadar tawas yang diberikan (8\%), semakin meningkatkan jumlah sel hepar yang nekrosis. Perlakuan berupa induksi tawas selama satu minggu diberikan pada tikus untuk mengetahui pengaruhnya terhadap histopatologi sel hepar. Jumlah sel hepar yang mengalami nekrosis pada kelompok kontrol positif lebih tinggi dibandingkan kelompok kontrol negatif. Berdasarkan hasil uji BNT didapatkan perbedaan signifikan antar kelompok $(p=0,000)$. Berdasarkan analisa Two Way ANOVA, didapatkan bahwa jumlah sel nekrosis pada zona I jumlah sel hepar yang mengalami nekrosis pada kelompok kontrol positif (tawas 2\%, 4\%, 6\%, dan 8\%) lebih tinggi dibandingkan kelompok kontrol negatif 5,76 $\pm 1,71$. Tampak jumlah nekrosis sel hepar terbanyak didapatkan pada zona I dibandingkan dengan zona II dan III.

Tabel 1. Perbedaan jumlah nekrosis sel hepar tikus yang diinduksi tawas

\begin{tabular}{|c|c|c|c|}
\hline \multirow{3}{*}{ Kelompok } & \multirow{2}{*}{\multicolumn{3}{|c|}{$\begin{array}{l}\text { Jumlah Nekrosis Sel Hepar per Lapang Pandang } \\
\text { (Rerata } \pm \text { Standar Deviasi) }\end{array}$}} \\
\hline & & & \\
\hline & Zona I & & Zona III \\
\hline Ко & $5,76 \pm 1,71 *$ & $8,08 \pm 1,69 *$ & $10,97 \pm 1,52 *$ \\
\hline K1 & $15,40 \pm 2,11 *$ & $11,32 \pm 1,97 *$ & $7,67 \pm 1,17 *$ \\
\hline K2 & $21,60 \pm 1,82 *$ & $19,11 \pm 1,98 *$ & $11,59 \pm 1,69 *$ \\
\hline K3 & $36,45 \pm 2,36 *$ & $27,97 \pm 2,43 *$ & $22,12 \pm 2,63 *$ \\
\hline K4 & $46,69 \pm 3,72 *$ & $39,16 \pm 4,26 *$ & $31,40 \pm 2,44 *$ \\
\hline
\end{tabular}

\section{Keterangan:}

KO: Kelompok kontrol negatif (tanpa diberi tawas)

$\mathrm{KI}$ : Kelompok dengan tawas $2 \%$

$\mathrm{K} 2$ : Kelompok dengan tawas $4 \%$

K3: Kelompok dengan tawas $6 \%$

K4: Kelompok dengan tawas $8 \%$

*: bila antar kelompok $\mathrm{K} 0, \mathrm{KI}, \mathrm{K} 2, \mathrm{~K} 3$, dan $\mathrm{K} 4$ berbeda signifikan pada $\mathrm{p}<0,05$ 
Hasil (Tabel 2) menunjukkan bahwa pemberian tomat ranti tanpa cabai rawit dapat mengurangi jumlah sel hepar yang nekrosis karena induksi tawas optimal jika dibandingkan dengan kelompok kontrol positif $(p=0,000)$. Pemberian perasan buah tomat ranti yang dikombinasikan dengan cabai rawit dapat meningkatlan jumlah nekrosis sel hepar tikus yang diinduksi tawas optimal jika dibandingkan dengan kelompok kontrol negatif $(p=0,000)$. Data yang diperoleh menunjukkan bahwa jumlah nekrosis sel hepar pada zona I kelompok kontrol positif lebih tinggi dibandingkan kelompok dengan suplementasi perasan tomat ranti. Jumlah nekrosis sel hepar pada zona I kelompok perlakuan dengan suplementasi tomat ranti yang dikombinasikan dengan cabai rawit lebih tinggi dibandingkan kelompok kontrol negatif dan kelompok yang hanya diberikan suplementasi perasan tomat ranti. Hasil tersebut menunjukkan bahwa induksi tawas menyebabkan nekrosis sel hepar terutama pada zona I dan suplementasi perasan tomat ranti mampu menurunkan nekrosis sel hepar yang diakibatkan oleh induksi tawas, namun suplementasi perasan tomat ranti yang dikombinasikan dengan perasan buah cabai rawit justru menyebabkan nekrosis sel hepar terutama pada zonal.

Tabel 2. Perbedaan jumlah nekrosis sel hepar pada pemberian perasan buah tomat ranti dan cabai rawit pada tikus dengan induksi tawas

\begin{tabular}{cccc}
\hline \multirow{2}{*}{$\begin{array}{c}\text { Kelompok } \\
\text { perlakuan }\end{array}$} & \multicolumn{3}{c}{$\begin{array}{c}\text { Jumlah Nekrosis Sel Hepar per Lapang Pandang } \\
\text { (Rerata } \pm \text { Standar Deviasi) }\end{array}$} \\
\cline { 2 - 4 } & Zona I & Zona II & Zona III \\
\hline B0 & $6,73 \pm 2,07^{*}$ & $8,19 \pm 2,08^{*}$ & $10,3 \pm 2,33^{*}$ \\
B1 & $33,63 \pm 5,26^{*}$ & $29,96 \pm 4,27^{*}$ & $24,49 \pm 4,86^{*}$ \\
B2 & $11,55 \pm 3,07^{*}$ & $9,39 \pm 2,42^{*}$ & $7,96 \pm 2,08^{*}$ \\
B3 & $14,89 \pm 3,25^{*}$ & $11,29 \pm 2,86^{*}$ & $9,31 \pm 2,38^{*}$ \\
B4 & $18,97 \pm 2,69^{*}$ & $14,92 \pm 3,19^{*}$ & $12,84 \pm 1,98^{*}$ \\
B5 & $27,71 \pm 2,75^{*}$ & $21,36 \pm 3,65^{*}$ & $19,08 \pm 2,83^{*}$ \\
\hline
\end{tabular}

Pada pemeriksaan kadar SGOT dan SGPT, pemberian tomat ranti dosis $50 \%$ memiliki potensi menurunkan kadar SGPT lebih kuat dibandingkan dengan kombinasi tomat ranti dan cabai rawit pada berbagai variasi dosis. Pemberian cabai rawit justru meningkatkan kadar SGOT dan SGPT (Tabel 3).

Tabel 3. Rerata kadar SGOT dan SGPT diet tomat ranti dan cabai rawit pada tikus yang diinduksi tawas

\begin{tabular}{cccc}
\hline No. & $\begin{array}{c}\text { Kelompok } \\
\text { Perlakuan }\end{array}$ & $\begin{array}{c}\text { SGOT } \\
\text { (Rerata } \pm \text { SD) }\end{array}$ & $\begin{array}{c}\text { SGPT } \\
\text { (Rerata } \pm \text { SD) }\end{array}$ \\
\hline 1. & BO & $11,85 \pm 4,36$ & $11,12 \pm 1,98$ \\
2. & B1 & $109,20 \pm 5,33$ & $128,46 \pm 2,50$ \\
3. & B2 & $52,28 \pm 3,89$ & $61,22 \pm 4,09$ \\
4. & B3 & $70,68 \pm 4,64$ & $79,22 \pm 3,34{ }^{*}$ \\
5. & B4 & $84,12 \pm 6,96^{*}$ & $90,01 \pm 1,96^{*}$ \\
6. & B5 & $89,61 \pm 10,73^{*}$ & $101,46 \pm 3,90^{*}$ \\
\hline
\end{tabular}

Keterangan: Tabel 1 dan Tabel 2

$\mathrm{BO}$ : Kelompok kontrol negatif (tanpa diberi tawas)

$\mathrm{BI}:$ Kelompok dengan tawas $8 \%$

B2: Kelompok dengan tawas $8 \%+$ jus buah tomat ranti $100 \%$

B3: Kelompok dengan tawas $8 \%+$ jus buah tomat ranti $100 \%+$ jus cabai rawit $25 \%$

B4: Kelompok dengan tawas $8 \%+$ jus buah tomat ranti $100 \%+$ jus cabai rawit $50 \%$

B5: Kelompok dengan tawas $8 \%+$ jus buah tomat ranti $100 \%+$ jus cabai rawit $100 \%$

* : signifikan bila $\mathrm{p}<0,05$

\section{DISKUSI}

Pengaruh Paparan Tawas terhadap Perubahan Histopatologi Hepar Tikus

Hasil pemeriksaan histopatologi jaringan hepar tikus pada kelompok kontrol negatif, yaitu kelompok tanpa perlakuan menunjukkan gambaran yang normal. Sel hepatosit berbentuk poligonal, tersusun radier membentuk lempeng hepatosit yang mengelilingi vena sentralis dan dipisahkan oleh sinusoid dengan sedikit jumlah sel nekrosis. Berbeda dengan hasil pengamatan yang dilakukan pada kelompok kontrol positif yaitu kelompok dengan induksi tawas menunjukkan adanya nekrosis yang luas terutama pada zona I. Hasil penghitungan sel nekrosis pada penelitian ini menunjukkan bahwa jumlah nekrosis sel hepar terbanyak didapatkan pada zona I dibandingkan dengan zona II dan III. Zona III terletak pada ujung mikrosirkulasi darah dan lebih sensitif terhadap gangguan sirkulasi serta defisiensi nutrisi daripada zona I dan II $(14,15)$. Zona I terletak dekat dengan pembuluh aferen yang menerima darah dengan kandungan nutrisi dari sirkulasi pencernaan. Darah mengalir melalui vena porta dan arteri hepatica sehingga bila tubuh terpapar zat toksik melalui makanan maka akan langsung didistribusikan oleh aliran darah ke jaringan hepar yang dapat diamati pengaruhnya pada zona I tersebut.

Secara teoritis, sel hepar tikus yang dipapar tawas akan mengalami kerusakan yang digambarkan dengan terdapatnya inti sel yang piknotik, karioreksis, dan kariolisis. Nekrosis adalah kematian sel dan jaringan pada tubuh yang hidup, yang ditandai dengan perubahan tampak nyata pada inti sel kerusakan ini bersifat irreversible (16). Perubahan morfologis yang pada stadium lanjut dapat berupa inti sel piknotik (kariopiknosis) yaitu pengerutan inti sel dan kondensasi kromatin, karioreksis yaitu pecahnya inti yang meninggalkan pecahan-pecahan sisa inti berupa zat kromatin yang tersebar didalam sel, dan stadium yang terakhir dari nekrosis adalah kariolisis yaitu penghancuran dan pelarutan inti sel sehingga inti sel menghilang, dapat berlanjut menjadi pecahnya membran plasma, dan akhirnya nekrosis (16). Sel yang kariolisis inilah yang diamati pada penelitian ini karena merupakan stadium terakhir dari nekrosis. Disamping nekrosis, terdapat pula apoptosis yang ditandai dengan adanya fragmentasi DNA. Pada apoptosis, sel mengalami pengerutan dan terpecah-pecah (10). Hepar memiliki potensi yang cukup besar untuk terjadinya peningkatan reaksi fenton ketika terjadi stress oksidatif karena sebagian besar besi dalam tubuh disimpan dalam sel hepatosit. Sel hepar mengandung sejumlah besar protein yang disebut apoferitrin yang dapat bergabung dengan besi membentuk ferritin (17). Translasi feritrin diatur oleh Iron Regulating Protein (IRPs) yang merupakan represor terhadap pembentukan ferritin (18). Stress oksidatif diketahui dapat menyebabkan aktivasi dari IRP-1 (18). Penurunan sintesis feritrin menyebabkan terjadinya peningkatan besi bebas yang berpotensi meningkatkan reaksi fenton, sehingga akan meningkatkan pembentukan radikal hidroksil. Peningkatan radikal hidroksil berimplikasi terhadap peningkatan lipid peroksidasi, fragmentasi protein dan DNA yang mencetuskan terjadinya jejas pada sel hepar, sehingga terjadi peningkatan nekrosis terhadap sel hepar. Pada saat terjadi stres oksidatif maka fosforilasi oksidatif akan menurun dan menyebabkan terjadinya penurunan terhadap pembentukan ATP. Penurunan 
pembentukan ATP menyebabkan transport aktif $\mathrm{Ca}^{2+}$ terganggu yang berakibat pada peningkatan $\mathrm{Ca}^{2+}$ sitosol (19). Peningkatan ROS akan menyebabkan terjadinya stress oksidatif karena tidak diimbangi dengan peningkatan antioksidan. Radikal bebas akan merusak membran sel, mitokondria, dan retikulum endoplasma sehingga terjadi peningkatan $\mathrm{Ca}^{2+}$ sitosol. Peningkatan $\mathrm{Ca}^{2+}$ sitosol akan mengaktifkan enzim fosfolipase, protease, endonuklease, dan ATPase yang menyebabkan terjadinya penurunan fosfolipid, gangguan protein membran dan sitoskeleton, fragmentasi DNA, dan penurunan ATP. Kondisi tersebut akan menginisiasi terjadinya kematian pada sel hepar (nekrosis).

Berdasarkan hasil penelitian ini jumlah nekrosis sel hepar pada kelompok kontrol positif lebih tinggi dibandingkan kelompok kontrol negatif menunjukkan bahwa paparan tawas menyebabkan kerusakan pada sel hepar. Selain itu, jumlah nekrosis sel hepar pada kelompok kontrol positif tertinggi didapatkan pada zona I yang menunjukkan bahwa paparan tawas bersamaan dengan makanan menyebabkan nekrosis pada sel hepar karena dari GIT langsung didistribusikan ke hepar melalui vena porta dan arteri hepatika sehingga zona I yang langsung terpapar bahan toksik tersebut.

\section{Pengaruh Diet sambal Tomat Ranti dan Cabai Rawit pada Induksi Tawas}

Pada penelitian ini digunakan tomat ranti untuk suplementasi karena diketahui memiliki kandungan antioksidan yang lebih tinggi dibandingkan tomat jenis lain. Beberapa peneliti menyebutkan kadar likopen, vitamin C, dan fenolik tomat ranti lebih tinggi dibandingkan L. esculatum dan L. peruvianum $(20,21)$. Berdasarkan penelitian Hassan dan Edrees menyatakan bahwa pemberian jus tomat sebesar $8,25 \mathrm{~mL} / \mathrm{Kg}$ BB yang setara dengan kebutuhan likopen setiap hari sebesar 1 $\mathrm{mg} / \mathrm{Kg}$ BB terhadap tikus dengan diet makanan yang digoreng dengan minyak goreng teroksidasi dapat menurunkan kadar LDH, CK, AST dan ALT serum pada hepar dan jantung tikus (22).

Cabai rawit digunakan untuk suplementasi karena paling banyak mengandung vitamin A dibandingkan cabai lainnya. Cabai rawit segar mengandung $11.050 \mathrm{SI}$ vitamin A, sedangkan cabai rawit kering mengandung mengandung $1.000 \mathrm{SI}$. Buah cabai rawit juga mengandung substansi fenol golongan terpenoid berupa capsaicin (69\%), dihydrocapsaicin (22\%), nordihydrocapsaici (7\%), homocapsaicine (1\%), dan homodihydrocapsaicin. Kapsaisin merupakan senyawa golongan terpenoid terbanyak dan terpenting (2). Beberapa antioksidan bila digabung mempunyai kemampuan yang lebih kuat. Kombinasi tersebut untuk melindungi sesama antioksidan agar tidak teroksidasi, siklus ini berjalan terus, dan dapat memelihara tubuh dari keseimbangan antioksidan (23). Penelitian ini mengkombinasikan dua bahan pangan yang diduga mengandung antioksidan dengan tujuan untuk meningkatkan kadar antioksidannya dan melihat apakah dua antioksidan ini dapat berjalan sinergis atau tidak berdasar indigenous food orang Indonesia.

Hasil pemeriksaan histopatologi menunjukkan bahwa kelompok suplementasi tomat ranti $100 \%$ dosis $1 \mathrm{~mL}$ memiliki gambaran sel hepar yang lebih baik dibandingkan kelompok kontrol positif dan kelompok perlakuan lainnya. Vena sentralis tampak normal, dikelilingi oleh sel hepatosit yang tersusun radier. Selain itu juga didapatkan sel hepatosit yang mengalami nekrosis, namun tidak sebanyak yang terdapat pada kelompok kontrol positif dan kelompok perlakuan lainnya. Data kuantitatif yang diperoleh pada penelitian ini yaitu dengan cara menghitung jumlah sel nekrosis pada tiap zona hepar menunjukkan bahwa tingkat nekrosis sel hepar kelompok yang menerima suplementasi tomat ranti sebelum induksi tawas secara signifikan lebih rendah dibandingkan dengan kelompok kontrol positif dan kelompok perlakuan lainnya. $\mathrm{Hal}$ ini sesuai dengan penelitian terdahulu yang menyebutkan bahwa pemberian ekstrak tomat mencegah kerusakan hepar tikus yang ditandai dengan penurunan kadar aspartate aminotransferase (24). memperbaiki kerusakan jaringan, indikator biokimia, dan parameter stress oksidatif (25). Kemampuan tomat ranti dalam mencegah kerusakan sel hepar diduga bahwa adanya likopen, vitamin C dan fenolik berfungsi sebagai scavenger radikal bebas yang potensial melindungi sel dari radikal bebas yang diakibatkan induksi tawas $(20,21)$. Mekanisme likopen dalam meredam radikal bebas diperkirakan melalui tiga cara yaitu dengan mengikat radikal bebas, transfer elektron dan menyumbangkan satu atom hydrogen (26). Tomat ranti juga mengandung vitamin C dengan konsentrasi yang cukup tinggi. Vitamin $\mathrm{C}$ merupakan antioksidan yang bersifat hidrofilik yang terdistribusi dalam cairan intrasel dan ekstrasel (27). Dalam meredam radikal bebas, vitamin $C$ akan memberikan atom hidrogen dari gugus- $\mathrm{OH}$ ke dalam radikal bebas, sehingga radikal bebas akan stabil dan tidak reaktif (28). Tomat ranti juga mengandung komponen fenolik yang merupakan antioksidan alami yang penting bagi jaringan sel manusia. Dalam proses meredam radikal bebas, fenolik akan memberikan atom hidrogen yang dimilikinya untuk bereaksi dengan radikal peroksil dan memutus reaksi rantai oksidasi (29).

Rubatzky dan Yamaguchi menyatakan cabai rawit merupakan pro-vitamin A dan vitamin $\mathrm{C}$ yang sangat baik (3). Menurut Hernani dan Rahardjo (kandungan vitamin C pada cabai rawit enam kali lebih tinggi dari pada jeruk dan kandungan vitamin A dua kali lebih tinggi dari pada wortel (23). Di dalam buah-buahan vitamin C hanya terdapat konsentrasi tinggi dibagian kulit buah, dan vitamin $\mathrm{C}$ dengan kadar rendah yaitu pada daging buah dan bijinya. Vitamin A merupakan salah satu jenis vitamin larut dalam lemak yang juga dikenal dengan nama retinol. Vitamin A berperan sebagai antioksidan yang membantu merangsang dan memperkuat daya tahan tubuh dalam meningkatkan aktivitas sel natural killer (NK), memproduksi sel darah limfosit, dan antibodi. Vitamin A dan vitamin $C$ yang terkandung dalam cabai rawit samasama berperan sebagai antioksidan.

Hasil pemeriksaan struktur dan fungsi hepar menunjukkan bahwa pemberian cabai rawit justru meningkatkan jumlah nekrosis sel hepar dan meningkatkan kadar SGOT dan SGPT. Diduga kandungan kapsaisin dalam cabai rawit bersifat sitotoksik. Kapsaisin dapat menginduksi kematian sel melalui beberapa mekanisme, diantaranya dengan mengaktivasi VR1; suatu non-selective cation channel; sehingga mengakibatkan influks ion berlebih, menghambat sintesis protein melalui kompetisi dengan tirosin, dan juga mengakibatkan penurunan potensial membran mitokondria yang disertai dengan pembentukan 
ROS. Paparan kapsaisin menyebabkan terjadinya respon inflamasi, stres oksidatif, dan DNA-strand breakage yang dapat mempengaruhi fungsi sel dan pada akhirnya dapat menyebabkan kematian sel $(30,31)$. Senyawa lain dalam cabai rawit yang diduga toksik pada kadar tertentu adalah alkaloid, flavonoid, terpenoid, dan streroid saponin. Cara kerja senyawa-senyawa tersebut adalah dengan bertindak sebagai stomach poisoning. Bila senyawa-senyawa ini

\section{DAFTAR PUSTAKA}

1. Supartono W. Indigenous Food. HEP-DAAD Workshop. Bogor, 12 Januari 2012.

2. Setiadi. Cabai Rawit Jenis dan Budaya. Jakarta: Penebar Swadaya; 2006.

3. Rubatzky VE dan Yamaguchi M. Sayuran Dunia 3 (Prinsip, Produksi, dan Gizi). Bandung: ITB Press; 1999.

4. Sambaiah K and Satyanarayana MN. Influence of Red Pepper and Capsaicin on Body Composition and Lipogenesis in Rat. Journal of Biosciences. 1982; 4(4): 425-430.

5. Tugiyono H. Bertanam Tomat. Jakarta: Penebar Swadaya; 2006.

6. Galiana-Balaguer L, Roselló S, Herrero-Martínez JM, Maquieira A, and Nuez F. Determinan of L-Ascorbic Acid in Licopersicon Fruits by Capillary Zona Electrophoresis. Analytical Biochemistry. 2001; 296(2): 218-224.

7. Nurrahman dan Isworo J. Pengaruh Lama Perendaman dan Konsentrasi Tawas terhadap Sifat Fisik, Kimia dan Organoleptik Ikan Tongkol Asap. Prosiding Seminar Teknologi Pangan PATPI. Malang, 2002.

8. Parulian dan Alwin. Monitoring dan Analisis Kadar Aluminium (Al) dan Besi (Fe) pada Pengelohan Air Minum PDAM Tirtanadi Sunggal. [Skripsi]. Universitas Sumatera Utara, Medan. 2009.

9. Haribi R dan Yusrin. Konsentrasi Aluminium pada Ikan Asap yang Direndam dalam Larutan Tawas. Prosiding Nasional. 2008; 1(1): 286-296.

10. Kumar V, Abbas AK, Fausto N, and Mitchell R. Cell Injury, Adaptation and Death. In: Kumar V (Ed). Robbin Basic Pathology 7th edition. Philadelphia: Saunders; 2003.

11. Mahdiyaksa, Sulistyowati S, Dewi E, dan Ratri A. Pengaruh Jus Tomat Ranti (Lycopersicum Pimpinellifolium Mill.) terhadap Kadar Sod (Superoxide Dismutase) dan MDA (Malondyaldehyde) Serum Tikus Wistar Setelah Aktivitas Fisik Maksimal. [Skripsi]. Universitas Islam Malang, Malang. 2011.

12. Damayanti DS, Athiroh AAS, dan Aini N. Pengaruh Ekstrak Pueraria lobata var. Kangean terhadap Kadar MDA, Reseptor $\alpha-1$ Adrenergik, Profil Lipid dan Remodeling Sel Otot Polos Aorta Tikus Hipoestrogen. [Publikasi]. Universitas Negeri Malang, Malang. 2007

13. Hairrudin. Pengaruh Pemberian Ekstrak Jinten Hitam dalam Mencegah Stres Oksidatif Akibat Latihan masuk ke dalam tubuh akan menyebabkan gangguan fungsi sistem pencernaan (32). Ini membuktikan bahwa kandungan kapsaisin dalam cabai rawit dalam kadar tertentu dapat bersifat toksik dan menimbulkan ancaman kesehatan. Dapat disimpulkan bahwa diet tomat dapat memperbaiki struktur dan fungsi hepar yang mengalami stres oksidatif, namun penambahan cabai rawait pada tomat justru menurunkan fungsi dan struktur hepar.

Olahraga Anaerobik pada Tikus Putih. [Tesis]. Universitas Airlangga, Surabaya. 2006

14. Underwood JCE and Cross SS. General and Systematic Pathology. Underwood, General and Systematic Pathology. 5th edition. Churchill Livingstone: Elsevier; 2005.

15. Hebel R and Stromberg MW. Anatomy of the Laboratory Rat. Baltimore: The William and Wilin Company; 1989.

16. Linder MC. Biokimia Nutrisi dan Metabolisme dengan Pemakaian secara Klinis. Jakarta: UI Press; 1992.

17. Hall JE and Guyton AC. Guyton and Hall: Textbook of Medical Physiology. 11th edition. Philadelphia: Elsevier Saunders; 2005; p. 862.

18. Orino K, Lehman L, Tsuji Y, Ayaki H, Torti SV, and Torti FM. Ferritin and the Response to Oxidative Stress. Biochemical Journal. 2001; 357(1): 241-247

19. Kumar V, Abbas AK, and Fausto N. Robbins and Cotran Pathologic Basis of Disease. 17th edition. Philadelphia: Elsevier Inc; 2005.

20. Rusçuklu and Dane. Characterization and Genetic Mapping of Health Related Traits in Tomato. [Thesis]. İzmir Institute of Technology, İzmir. 2005

21. Hemaprabha E and Balasaraswathi R. Internal Quality Characterization and Isolation of Lycopene Specific Genes from Tomato. Journal of Applied Horticulture. 2008; 10(1): 24-29

22. Hassan HA and Edress GM. Therapeutic Effect of Lycopenene-rich Tomato Juice on Cardiac Disorder in Rats Feed on Fried Food in Oxidized Frying Oil. The Egyptian Journal of Hospital Medicine. 2002; 14: 115126.

23. Hernani dan Rahardjo M. Tanaman Berkhasiat Antoksidan. Jakarta: Penebar Swadaya; 2002.

24. Kim Y, DiSilvestro R, and Clinton S. Effects of Lycopenebeadlet or Tomato-powder Feeding on Carbon Tetrachloride-induced Hepatotoxicty in Rats. Phytomedicine. 2004; 11: 152-156.

25. Jamshidzadeh, Akram, Baghban, et al. Effects of Tomato Extract on Oxidative Stress Induced Toxicity in Different Organs of Rats. Food and Chemical Toxicology. 2008; 46(12): 3612-3615.

26. Krinsky NI and Johnson EJ. Carotenoid Actions and Their Relation to Health and Disease. Molecular Aspects of Medicine. 2005; 26: 459-516.

27. Victor VM, McCreath KJ, and Rocha M. Recent Progress in Pharmacological Research of Antioxidants in Phatological Conditions: Cardiovascular Health. Recent Patents on Anti-Infective Drug Discovery. 
2006; 1(1): 17-31.

28. Widyatmoko and Brillian Sonny. Aktivitas antioksidan Vitamin C dan E pada Kadar SGOT dan SGPT Serum Darah Tikus Putih yang Terpapar Allethrin. [Skripsi]. Universitas Negeri Semarang, Semarang. 2009.

29. Ermilova EV, Kadyrova TV, Krasnov EA, Pisareva SI, and Pynchenkov VI. The Antioxidant Activity of Black Crowberry Extracts. Pharmaceutical Chemistry Journal. 2000; 34(11): 28-30.

30. Cochereau C, Sanchez D, and Creppy EE. Tyrosine
Prevent Capsaicin-induced Protein Synthesis Inhibition in Cultured Cells. Toxicology. 1997; 117(23): 133-139.

31. Gallati G and O'Brien PJ. Cytoprotective and Anticancer Properties of Coenzym Q versus Capsaicin. Biofactors. 2003; 18(1-4): 195-205.

32. Richeux F, Cascante M, Ennamany R, Saboureau D, Sanni A, and Creppy EE. Implication of Oxidative Stress and Inflammatory Process in the Cytotoxicity of Capsaicin in Human Endothelial Cells: Lack of DNA Strand Breakage. Toxicology. 2006; 147(1): 41-49. 